\title{
Identities in Transition: Hybridism amongst Second Generation Greek Migrants
}

\author{
By Andrea Pelliccia*
}

\begin{abstract}
The principal originality of this article lies in the analysis on ethnicity and identity in an under-explored geographical/ethnic context, that is the Greek second generation in Italy. Through a field research, the article analyses second generation Greek migrants' process of identity construction, highlighting the emergence of a network of multiple and hybrid belongings as well as a combination of identities and dialectical positions. The field research findings show that hybrid belongings contradict the idea of cultural purity by revealing that all cultures are hybrid all along. In fact, self-representation and self-identification of the Greek second generation challenge traditional paradigms of ethnicity entailing a reworking of pre-existing hybridity rather than any simple combination of Italian and Greek identities. Another key argument that emerged from this fieldwork is the importance of the specific context, positions and conditions in which hybridity operates.
\end{abstract}

Keywords: Hybridity, hybrid identities, Greekness, Greek second generation, Italy.

\section{Introduction: Notes on Hybridity Theory}

In the recent decades, concepts such as hybridity and hybridisation have attracted attention of many scholars who have dealt with issues relating to the identity and construction of subjectivity in the contemporary age, particularly on the second and third generation migrants (e.g. Asher 2008, Brettell and Nibbs 2009, Butcher 2004, Conor 1991, Feinberg 1993, Hyun 1995, Kosuka 1989, Liu 1998, Lowe 1991, Matsuda 2001, Moran 2016, Nayak 2003, Ngan and Chan 2012, Nilan and Feixa 2006, Pilkington and Johnson 2002, Plaza 2006, Tamayo Lott 1997, Wang and Collins 2016, Yang et al. 1997). The wide literature on hybridity covers topics such as globalisation vs the local, post colonialism and migrant identities (Leavy 2008: 167). Hybridity is used within cultural and post colonial studies and the term is often related to studies of diasporas, immigration and biculturalism, and questions about new identities and ethnicities (Anthias 2001, Hall 1996). According to Bhabha (1994), one of the precursors to the development of this concept and one of the most important scholars in contemporary post colonial studies, hybridity challenges any fixed authenticity or fixed meaning, by questioning a sense of authenticity in distinctions and dichotomies such as management/culture, humans/nonhumans and traditional/modern. Moreover, hybridity has become a key

\footnotetext{
* Researcher, Institute for Research on Population and Social Policies, National Research Council of Italy.
} 
concept not only within cultural and postcolonial studies, but also within most of the post-theories (Hutnyk 2005). Shifting from post colonialism to globalisation (Nederveen Pieterse 2005), the hybridity theory is adopted as an epistemological tool for understanding transnational and diaspora contexts in the globalized word by the application of theoretical frameworks in empirical research (e.g. Ang 2001, 2003, Burke 2009, Dhingra 2007, Iyall Smith 2008, Kraidy 2005, O'Connor 2010, Yow 2010).

The hybridity theory has as its privileged object of study the mixing of cultures and the irrelevance of cultural borders. As an empirical and historically detectable principle of human history, hybridity is seen both as a result and as a cause of the systematic encounter of different cultures. Within the current epistemological debate, the hybridity theory contrasts with the cultural differentialism theory (Al-Azmeh 1993, Taguieff 1987). The latter is based on an interpretative model oriented toward the crystallization of cultures which are considered as an essential, rigid and monolithic entity. Such a perspective went through many centuries, from the days when Greeks labelled people who did not speak the Greek language as "barbarian". Later, it was adopted during the Romantic era, when the speaking language was considered a key element in establishing the belonging to the nation. It was also used by the nationalist and racist ideologies which linked local culture and language, or believed that culture was biologically determined. In the twentieth century, anthropology, especially in reference to colonial and non-western countries, by developing the cultural relativism theory, has continued to think culture as a whole, objectifying and enclosing it within clearly defined boundaries. As a result, concepts such as "Jewishness", "Germanness", "Greekness", "Japaneseness" were placed, once again, within an essentialist dimension (Nederveen Pieterse 2005).

While placing itself in opposition to cultural differentialism, the hybridity theory changes the notion of self-centred culture which formed the cornerstone of romantic nationalism, racist ideology, ethnicism, religious revivalism and cultural essentialism. By focusing on the crossing of cultural boundaries, pluralism, mixing and non-fixity, hybridity theory contrasts with all those essentialist discourses and those identity politics based on the idea of purity (Mitchell 1997). Both diaspora and hybridisation involve a form of space that Bhabha (1994) defines "third space", namely the inbetween space that allows the emergence of new cultural positions and is inherently critical of essentialism and conceptualisations of original culture. It is a space from which culturally different subjects can resist hegemonic narratives of race, culture and nation, by negotiating new positions. Hybrid positions are considered fluid and continually in a process of becoming, allowing individuals to replace essentialist notions of ethnic and national identity with new representations.

Such a perspective reflects a post-modern cultural blending and transgression that is an epistemological passage from Cartesian dichotomous paradigm to decolonising our imaginary and deconstructing the notion of an imagined community. Hybridisation does not entail an 
elimination of cultural diversity. Rather, it produces forms of intercultural communication that support and renew that variety, not only as a source but also as an empirically observable result. What is important is to look at the cultural diversity not as a predefined entity, but as a fluid relationship between cultures in continuous blending and never separate. In fact, we are not in presence of a mosaic made of separate pieces with hard and welldefined edges, but of an idea of fluid, dynamic and travelling cultures (Hannerz 1992). The hybridity perspective problematizes the boundaries but does not deny their existence. What it claims is the incessant crossing. Boundaries probably never will fade because they are a function of social life, in light of the fact that phenomena such as migration, racism, nationalism, religion, regionalism and urban ghettoisation confirm and reinforce the existence of borders. In fact, globalisation has resulted in the reinforcement of both supranational and sub-national regionalism, while leading often to the universalisation of particularism, that is, the global reach of particular identities. A case in point is represented by the effects caused by the European Union, where sovereignty is renewing its meaning by involving regionalism and sub-regionalism.

Thus, hybridity represents a challenge to all local claims to separate identities and fanaticism of cultural boundaries, affirming an idea of society that is reducible neither to a uniform configuration, nor to a fragmentation of separate national units. This occurs because the global society is made up of hybrid formations, times and places which are fostered by migration and diasporic movements. In a globalized world characterized by technological revolution as well as rapid and massive flows of information, goods and people, it is not sustainable to speak of natural and cultural units. It is more accurate to speak of continuity and discontinuity processes that make the culture fluid, dynamic and syncretic (Amselle 1999). In the era of globalisation these dimensions of human mobility are rapidly increasing and helping to create hybrid forms of cultural identities (Anthias 2001, Appadurai 1996, Bhabha 1994, King 2010, Werbner 2001).

\section{Field Research on Greek Second Generation in Italy: Objectives, Methods and Data}

There is a large body of literature on the issue of hyphenated identities from the older-established Greek diasporas, spanning all continents (mostly from North America, Europe and Australia) and touching on both contemporary and historical diasporic experiences (e.g. Afentoulis and Cleland 2015, Angouri 2012, Callinicos 1990, Christou 2006a, 2006b, Chryssanthopoulou 2009, Costantakos 1980, Hionidou 2012, Kapardis and Tamis 1988, King et al. 2011, Kontos 2009; Koukoutsaki-Monnier 2012, Panagakos 2004, Petronoti 2009, Popov 2010, Tsolidis 2009, Unger 1986).

Many works analyse the identity of the Greek diaspora communities in terms of a constant attachment to a "mother-nation" and consider Greekness a fixed, organic and homogeneous entity (e.g. Constantinou 1999, 
Constantinou and Harvey 1985, Georgakas 1987, Komondouros and McEntee-Atalianis 2007, Kouvertaris 1997, McDuling and Barnes 2012, Moskos 1999, Psomiades 1987, Saloutos 1964, Scourby 1980). This means that the study of Greeks all over the world is based on an interpretative model oriented toward cultural crystallization, whereby the nationhood is closely linked to an ecumenical and transcendent Hellenism made of symbolic constructions, memories, reconfigurations of identity, and collective belonging. In this sense, language, religion, family, and kinship are seen as powerful markers defining Greeks as a whole within ethnoreligious and cultural boundaries.

Against these essentialist discourses and by using post-modern and post-structuralist reconceptualisations of diaspora, other scientific contributions on the Hellenic diaspora and Greek second generation have focused their attention on issues related to the excessive cultural emphasis among Greek communities abroad (Abatzopoulou 1997, Angouri 2012, Anthias 2002, Christou 2001, Frangoudaki and Dragonas 1997, King and Christou 2009, Koukoutsaki-Monnier 2012). Substantially, these scholars challenge the notion of self-centred cultures, affirming an idea of identity that is not reducible to a uniform and stable configuration. On the contrary, they argue that Greek identity is constantly performed, negotiated and coconstructed. It appears to be not a predefined and durable entity, but a result of an ongoing and intergenerational dynamic process. Thus, Greek diaspora is understood in terms of fluid allegiances and belongings, including hybrid modes. Moreover, the concepts of location and positionality are seen as useful tools allowing a total abandonment of essentialism and exploring processes and outcomes of collective identifications.

Apart from some contributions (Chasiotis et al. 2006, Korinthios 2012, Kornetis 2007, Manousakas 1991, Nikas 1991, Pelliccia 2012, Solaro 2006), relating mainly to a specific geographical area or a peculiar sub-population, contemporary Greek diaspora in Italy has not been adequately covered by the historical and social disciplines yet. This is even true for second generation Greek migrants. In fact, the literature does not have that much information on this population.

In the light of the lack or fragmentation of the scientific production on this topic and in order to fill this gap, a research project concerning contemporary Greek diaspora in Italy was designed and implemented. Thus, the principal originality of this paper lies in the analysis in an underexplored geographical/ ethnic context, which deserves much further research.

In particular, a long-term and thorough fieldwork on second generation Greek migrants was carried out, namely persons currently living in Italy with at least one parent of Greek nationality. In addition to individuals born in Italy, those people who moved to Italy at the age of no more than six years old (preschool age) were included, by virtue of the fact that, despite the statistics on population census that registered them as foreign-born, sociologically they are virtually indistinguishable from the narrow definition of the second generation. This fieldwork has set many objectives and has 
investigated many topics such as the family history, the process of identity construction, the sense of Greekness, the degree of involvement in the Hellenic institutions and "sites of belonging", roots tourism, transnational practices, and the phenomenon of counter-diaspora. The purpose of this paper is to analyse one of these topics that is the second generation Greek migrants' process of identity construction, and aspects and mechanisms of self-perception and hetero-perception. During the fieldwork they were asked how they perceive themselves and how they are perceived by others in terms of cultural identity. In the light of the debate between hybridity theory and the cultural differentialism theory, the principal research question concerned the formation and development of their hyphenated identities and their cultural boundaries: how second generation Greek migrants consider and perceive their biculturalism? In the event that we are dealing with hybrid identities, the questions are: how to avoid falling into essentialist traps since the use of mixing could, in turn, imply the notion of purity of "pre-mixed" entities? How to cope with the rhetoric of a new potential essentialism that crystallizes biculturalism within fixed and inflexible cultural boundaries? Moreover, negotiation of their Greekness in Italy by managing their hyphenated identity boundaries, and relations of "othering" for self-attributions and hetero-attributions were investigated. Here, the research questions concerned processes and outcomes of individual and collective identifications: how identity formation amongst second generation Greek migrants reflect their Greekness related to othering? Could the concepts of location and positionality be useful for shaping their Greekness?

During the fieldwork 70 life stories were collected through in-depth interviews, from May 2014 to February 2015 in many different places in the city of Rome: from environments symbolically and practically more effective and "secure", such as the workplaces or home of the author and the interviewees, up to more neutral and functional areas such as bars, restaurants and squares. Life stories have allowed us to explore research questions with a depth and breadth not possible in quantitative surveys. They have permitted to approach participants from different positions, to compare and understand their viewpoints with specific reference to the formation and development of their hyphenated identities. In addition, wherever possible, the technique of direct and participant observation, informing involved people, has also been used. Observations took place as a reference context within the workplaces and during Greek recreational or cultural events such as festivals, concerts, book presentations, conferences and so on. They allowed for a greater understanding of the Greek second generation members in their daily life and created an environment of shared meanings useful for focusing on the research topic. For the purposes of the interviews, second generation Greek migrants have been contacted through strategic points for sampling, such as Greek institutions (Greek Embassy, Consulates, and the Federation of Greek Communities and Brotherhoods of Italy) and some Italian-Greek associations/ foundations. In addition, the identification of various informants from the Hellenic Community of Rome 
has helped to reduce the time of the execution phase and has allowed for the removal of many obstacles in creating a climate of confidence, socialization and mutual understanding.

In reference to the socio-demographic characteristics, the data show a rather slight majority of women than men $(53.2 \%$ and $46.8 \%)$, while as for age, the target group is predominantly young (10-34 years). Almost all were born in Italy $(82,6 \%)$, only a very small minority in Greece $(13,6 \%)$ or in other countries $(3,8 \%)$. In reference to citizenship, by aggregating all cases including Greek citizenship, nearly four out of ten are Greek nationals. With regard to marital status, considering the young age of most of the interviewees, more than half are single $(61.8 \%)$ and have no children $(66,7 \%)$. In most cases $(92,3 \%)$, the reference target is made up of children of mixed marriages, almost always one parent born in Greece and one born in Italy. As regards the migratory experience of their Greek parents, the 1970s were the decade with the most impressive migration flow. Finally, analysing the reasons that prompted the parents to move to Italy, the research results show that the main reason was migration for university study. In fact, especially in the 1970s, Italy was an attractive destination for reasons related to study. The main push-factor for the Greek student migration depended on the exclusion from the Greek university system, together with previous post-conflict remedial operations in the Italian university system (such as reparations regarding the Second World War or the abolition of taxes), the favourable currency exchange, the equivalence of diplomas, the equivalence of periods of university studies and the recognition of foreign university qualifications. It should be emphasized that, in those years, well over half of the Greek students who went abroad chose Italy as their destination for study (Pelliccia 2014).

\section{Findings of Field Research: Hybrid Identities and Relations of "Othering"}

In this section, second generation Greek migrants' process of identity construction, and aspects and dynamics relating to self-perception and hetero-perception will be analysed. As mentioned above, participants in the present study were asked how they perceive themselves and how they are perceived by others in terms of cultural identity.

The narratives collected show that we are in the presence of hybrid selfdefinition and coexistence of hyphenated identities. They refer to "hybrid", "hyphenated", "layered", and 'multiple' identities, as the result of new amalgams that are neither predominantly of the country of origin nor that of settlement. They feel in many ways as "Italo-Greeks", "Greek-Italians", "Italians with Greek roots", or, to a lesser extent, "Mediterraneans", "Europeans" and so on. Many of them claim that this process of cultural perception has changed over the years and continues to manifest in overlapping forms of Greekness. Thus, we observe a process of selfidentification of a dense set of forms of cultural identities. 
Culturally I feel totally double. When people ask me where I'm from, I always say that I'm Italo-Greek. Ever since I was little, I said that I was Italo-Greek. I live in the "middle", my identity is hybrid. I feel good! (Maria, female, 31 years).

Previously, I considered myself Italian with Greek origin because I was born in Italy and I have always been living in Italy. Later, I began to consider myself Italo-Greek and my Greekness has changed. But it's not half and half. It's a mix. I would define it more like a hybrid identity. This identity is the result of cultural influences. For examples, sometimes I also feel a Mediterranean identity as both Italy and Greece are Mediterranean countries. For this reason we say "one face one race! " (Nicola, male, 25 years).

From the above interviews, hybridity entails mixing, combining culture and cultural exchanges, and a fusion of cultural influences is the end result. Many interviewees say that they mix Italian and Greek elements together, thereby affirming their bicultural identities as aspects of both cultures that are combined and synthesized (Ang 2001, Dwyer 2000, Neuliep 2009, Phinney and Ong 2007). This means that hybridity refers to the cultural overlapping of different ways of thinking and behaving. Italian and Greek cultures are present, no matter to what extent.

Nevertheless, now one could object that this cultural fusion could introduce the notion of purity of "pre-mixed" entities since the use of mixing could imply the purity of cultures. Consequently, biculturalism is supposed to be considered as two distinct, immutable and monolithic cultures. Hybridity theorists have had to cope with this problem reflecting on the existence of an anterior pure that precedes mixture (Chambers 1996, During 2005, Gilroy 1994, Hutnyk 2005, Nederveen Pieterse 2005). In fact, using the concept of hybridity may paradoxically evoke static and prior nonmixed elements. However, the results of this fieldwork provide an adequate answer to this problem. As reported by the words of the interviewees below, as well as many other participants in the present study, even the hyphenated identity presupposes a pre-existing hybridity, as well as the end result. Therefore, there is real awareness of a form of identity that is not the simple combination and sum of two distinct cultures but a new product, which is in turn born as a hybrid form. Hybridity, then, is not just another synonym for generalized cultural blending. For one thing, it entails a reworking of hybrid existing elements rather than any simple combination of Italian and Greek identities.

Formally, I'm supposed to be Italian with Greek roots. But I feel I have a hybrid identity, a combination of elements from two cultures. Also for the fact that my parents are a mixed couple, my father is Greek and my mother is Italian. While having this sort of differentiation I don't feel two separate identities but an identity that it is composed of several 
things. In the past, the questions I asked myself everyday were: "who am I?", "Am I Italian or Greek?". Nowadays, this is no longer the case. Because I have the full awareness that I have always had a hybrid identity ever since I was little. And this identity is something different. It is not the simple sum of Italian and Greek cultures. It's not easy to explain in words... (Andrea, male, 38 years)

I don't feel a well-defined identity, whether Italian, Greek, GreekItalian or Italo-Greek. I think that the search for a unique identity brings anxiety and stress. Actually, I feel many things, it's a sort of a huge container, a big chaos of feelings and identities that float and are constantly changing. I always had this hybrid perception. And also this feeling is always changing. (Caterina, female, 29 years)

The interviewees' words lead us to affirm that hybridity is a useful concept in terms of questioning boundaries that are considered insurmountable or essential. In this sense, the power in this concept is that it contradicts the idea of cultural purity by revealing that all cultures are hybrid all along. Self-representation and self-identification of Greek second generation deny the idea of pre-existing pure categories by challenging traditional paradigms of ethnicity and designating the formation of a new (hybrid) identity that may have a more transethnic character. These new hybrid identities are not strictly confined to a specific ethnic group (Greek or Italian). On the contrary, we are dealing with an amalgam and a cultural interpenetration that transgress national or ethnic boundaries and challenge dominant homogeneous cultural categories. In other words, as it was noted by other authors (Burke 2009, Nederveen Pieterse 2005), cultures are deeply and inherently mixed all along, because mixing is intrinsic to the existence of human beings and all cultures are subject to an incessant hybridisation process.

Culture, as a sphere of attribution of socially shared meanings, is permanently inside a process of construction, deconstruction and reconstruction. This means that no culture is ontologically immutable, fixed, rigid or static. Identity, especially in reference to the second generation, is not a stable and predefined entity but it belongs to a continuous and dynamic process that is constantly negotiated and co-constructed among interacting actors. As stated by Hall (1996: 4), nowadays identities are increasingly fragmented and multiple. Moreover, they are built through intersecting and antagonistic discourses, practices and different locations. Consequently, identities are subject to a radical historicisation and constant transformation.

The hyphenated identity "Italo-Greek" reflects both the identification with ancestral ethnicity or diasporic lineage and with society in general. For this reason it is always in relation with the "other". Alluding not so much to lifestyles and practices present in a particular group, but rather the meanings ascribed to such practices, cultural identity experiences a continuous process of transculturalism (Basch et al. 1994, Hannerz 1996, Vertovec and Cohen 
1999). The plot of these meanings is the result of complex interactions that launch the construction and representation of cultural identities that individuals use to make sense of their place in the world. Therefore, ItaloGreek identity is well constructed and reconstructed through a series of social exchanges and relationship systems, where not only is the "local identity" fundamental but also the identity that an individual has with that place or those places within a bidirectional relationship between Italy and Greece. In this sense, as argued also by Dhingra (2007: 263), it is important to consider the cultural fragmentation that results from being pulled in opposing direction and to identify plural cultural locations where hybrid performances take place. As a result, it is more accurate to speak of plural identities that are not only constantly negotiated but also positional and situational (Andall 2002: 396). The situational approach highlights the socially interactive process of ethnicity, in which cultural differences are communicated through interpersonal encounters and axes. By using Yow's words, "firstly, one axis of identity (like ethnicity, Author's Note) must be understood as in relation to other axes [...]. Secondly, identity shifts fluidly from setting to setting, so that not all axes are equally foregrounded in every situation" (2010: 8). This means that Greekness is articulated within a range of different contexts and situations, where the Greek second generation often uses strategies through which identity is constructed contextually in relation to others. This implies that, according to circumstances and the interlocutor, the interviewees confirm or transform the boundaries of their group - what Barth calls "ethnic borders" (1969) - understood as a social construction and as a communication mode that limits and at the same promotes the interaction. In fact, Greek second generation members define their sense of belonging according to the person they are facing and the context of communication. The assertion of identity is thus equivalent to defining a principle of discrimination against "others" and building a border that expands and contracts, weakens and strengthens. In regards to identity, hybridity relates to these strategies in expanding and crossing the ethnic borders by volition and agency (Dhingra 2007, Plaza 2006), also creating a new hybrid culture, creativity and cultural imagination (Lo 2002).

My identity is never the same. I change according to people in front of me, to the places where I live, if I am in Italy or in Greece. For example, when I am in Italy with my Italian friends, I tend to show especially my Greekness. When I'm in Italy with my family from the Greek side, I don't need to highlight my "Greek version". Instead, in my work environment, where I deal with issues related to Greece, my Greekness comes out. In short, it is an identity that is continuously being reshaped and it's never the same. (Elena, female, 27 years)

Generally, when I have to explain my surname, I have always answered that I'm fifty-fifty, half and half. Then, over time, I realized that this answer was not correct because half and half did not describe well my feeling. It really depends where I am. When I'm here at work, Greece 
goes a bit in the background, while when I'm in Greece it's different. I would say that I feel one hundred per cent Italian. But when I'm in Greece, in some situations, I can feel one hundred per cent Greek, in the way of thinking. Therefore, I would say that I'm not half and half but one hundred per cent Italian and one hundred per cent Greek. I would not say neither Italian nor Greek. Because it has never been a disadvantage, it has never made difficult to live here, it has never created a sense of incompleteness. Even there, because I am convinced that if I went to live in Greece, I would be fine. So, it is closely related to the context, the situations, the human interactions. (Marinella, female, 50 years)

Through the development of hybrid identities, there is a wide choice of "ethnic options" (Waters 1990): the second generation members can choose one or many options from their ethnic backgrounds while emphasising or attenuating their Greekness. This choice of Greekness is influenced by several factors: importance attached to ancestral identity, knowledge of ancestors, citizenship, language, surname, physical appearance, mixed marriage, religious affiliation, acculturation process and so on.

Being Italian-Greek is different from being only Italian or only Greek: it means a person with Greek culture who lives in Italy. But I don't consider myself a Greek of Italy. I was born and grew up in Italy, I attended Italian school, my manners and modes of dress are more Italian than Greek. I have better knowledge of Italian history than Greek history. But, on the other hand, I don't consider myself not Greek. Because half of my family lives in Greece, I have a Greek surname, I am first-born male of the family and, therefore, I feel a representative of my father's family. My world is a big container from which I can draw on and choose from time to time. (Loukas, male, 20 years)

Following this "bicultural eclecticism", that is the process through which individuals choose elements of the two cultures that best suit their particular circumstances or preferences (Paulston 1992: 125), second generation Greek migrants do not perceive their dual sense of belonging as a temporary condition pending stabilization. They participate in different cultures and create, with different materials produced in specific situations, their personal identities and combine them syncretically. Even the term "Italo-Greek" assumes a hybridity that occurs when, in a mutual way and in relation to different contexts or periods, they confirm "reflective symmetry of strangerhood" (King and Christou 2010: 181) when they say to feel "a little more Greek" in Italy, "a little more Italian" in Greece and "ItaloGreek" in another country. This means that hybridity is useful in capturing the complexity of influences on identities and in understanding meanings of complex relationships as form of becoming, rather than as a fixed being. In fact, rather than living in particular (fixed and monolithic) cultures, Greek 
second generation members find themselves on the interfaces between cultures, in contexts where they interact and interconnect. Thus, it is possible to view hybridity as an in-between or a third place (Bhabha 1994) where Greek second generation is "the condition of immanent potentiality that harbours the very possibility of their coming into being" in a fluid sense (Whatmore 2002: 161).

My dual identity emerges especially when I'm in a third country, such as when I lived in Istanbul where I studied for "Erasmus": there was no need to be labelled as Italian or Greek, because I was both of them. In Turkey, in a third and neutral country, relationship between Greek and Italian elements was more balanced. So, my identity is fluid. After my experience of living in Turkey, it is changed again and became a new form. (Matteo, male, 25 years)

The distance between self and other could become ambiguous. It is interesting to note how the identity of the Greek second generation turns out to be a compromise between self-identity and hetero-identity. In effect, many participants talk of the process of labelling towards them: in Italy they are often called "Greek" and in Greece they are often called "Italian". But this labelling changes constantly at different stages of life, according to people and contexts, while reshaping their borderland and diasporized hybrid identities, and relational being. Furthermore, this has to do not only with relational being but also with relational becoming because of the fluidity and the web of collective interactions and heterogeneous ways of becoming.

It depends on the context: when I'm in Italy they call me "the Greek", when I'm in Greece they call me "the Italian". But sometimes they even invert this labelling. I should always feel out of place. It is really weird but now I'm used to this labelling by others. (Manuela, female, 21 years)

This labelling does not always coincide with self-perception. On the contrary, often self-identity is in a dialectical relation with the process of cultural categorization that is the imposition of identity from the outside (Fabietti 2003: 138). As a result, the process of cultural labelling and social categorization can transform hybridity into a double absence, embodied in feeling neither "Greek" nor "Italian". As well argued by Ang (2001), hybrid identity may produce a vulnerable in-betweenness where senses of belonging are entwined but none are complete. Some interviewees, in their being neither entirely Greek nor entirely Italian, say that they have experienced a sense of disorientation that implies a difficulty of immediate access to a defined identity and that drives them to review their boundaries and thus to develop new forms of identity. 
My Greek paternal roots have determined my whole life: my choices, my job, my passions, my sacrifices, my joys. My Italian maternal roots made me realize how difficult is to live in a country while carrying another country in my heart. Those people who belong to a diaspora are neither entirely Greek nor entirely Italian. We are indebted to both countries. We are divided forever. "Returning" to a country that belongs to us means leaving another country that also belongs to us. Our identity is always unfinished and is increasingly being brought into question. (Antonio, male, 27 years)

For some members of Greek second generation subsequent visits to the homeland could play a significant role in reinforcing their homelandidentity whilst for others visits may heighten their sense of hybridity or even create new and hybrid identities (Kibria 2003, Louie 2004, Stephenson 2002). The formation of a re-shaped hybrid identity inevitably necessitates a re-evaluation of the relationship with the homeland and its significance to identity.

While travelling to their ancestral homeland, most of participants in this research claim to be placed in a condition more properly hybrid, between the tourist and the local resident, crossing a symbolic threshold and entering a social and cultural limbo. In fact, they occupy a middle zone, a condition of third space between outsider and local resident, between tourist and a local. This interstice is determined, from time to time, by particular social interactions, categorizations and relationships with others, such as relatives and friends. Also in this case, the in-between position can also be interpreted by following the situational approach, in the sense that the oscillation between tourist and local varies according to different situations and contexts. Thus, visits to Greece facilitate the creation of this third space within which second generation Greek migrants can both recognize and question associations with Greece. In this space they can sometimes be a part of a collective identity of being "Greek", or associate with a more hybrid identity of being "more or less Greek" or "not that Greek", according to context. The identity boundaries are not always the same. For example, they may feel local in the specific place of origin of their parents but not in the entire Greek territory. Similarly, the boundaries expand or shrink in relation to the human context in which they are immersed, by the virtue of the fact that this context can be constituted by familiar (relatives or friends) or unknown people, or when they have new life experiences or create meaningful relationships.

When I am in Greece I perceive myself as a hybrid form, neither as local nor as a tourist. There is a love that goes beyond mere tourism. (Nina, female, 28 years)

I often go to Greece, especially to Crete where I have a family house. Apart from Crete, I also visit other parts of Greece. But my status in Greece varies based on where I am. If I am in Crete I feel more at 
home, because I have my loved ones and roots. I feel a bit between a local and tourist. On the contrary, when I travel around Greece I feel and behave as a tourist, but always with a special status. (Maria, female, 31 years)

\section{Conclusions}

This paper attempts to provide a contribution to ethnicity and identity studies in order to identify the use of these concepts within new contexts of globalisation and interculturalism. Such a contribution can be added to all other studies which analyse issues relating to identity and construction of subjectivity in the contemporary age, particularly to the second generation. Moreover, since there is no literature concerning the Greek second generation in Italy, the principal originality of this work lies in the analysis on ethnicity and identity in an under-explored geographical/ethnic context, which deserves much further research.

Studying the Greek second generation allows us to analyse concepts such as identity, belonging, nation, and citizenship, within the relationship between homeland and diaspora. In this paper dynamics of identity construction have been analysed, by highlighting the emergence of hybrid forms of identity. The concept of hybridity is useful in explaining the experience of diasporized individuals, particularly of second generation, as it accounts for the complexity of how identities are formed in a negotiation between homeland and host cultures.

Within the current epistemological debate, the hybridity theory contrasts with the cultural differentialism theory that is based on an interpretative model oriented toward the crystallization of cultures which are considered as essential, rigid and monolithic entities. While placing itself in opposition to cultural differentialism, hybridity theory changes the notion of a self-centred culture. By focusing on the crossing of cultural boundaries, pluralism, mixing and non-fixity, hybridity theory contrasts with all those essentialist discourses and those identity politics based on the idea of purity.

The first purpose of this paper has been to analyse the formation and development of second generation Greek migrants' hyphenated identities and cultural boundaries. The principal research questions concerned how they perceive their biculturalism and how to cope with the rhetoric of a new potential essentialism that crystallizes biculturalism within rigid and static cultural boundaries. Through the fieldwork it is emerged that Greek second generation diaspora is a network of multiple and hybrid belongings as well as a combination of identities and dialectical positions. To avoid falling into the same error of cultural essentialism, that is purity of cultures, this paper states that hybridity has always existed. In fact, the main result of this research is that hyphenated identity presupposes a pre-existing hybridity, as well as the end result, and hybridity is more than any simple combination of Italian and Greek identities. Hybridity calls into question the boundaries as well as the codes that sustain them. It is capable of overcoming the 
restrictions of national boundaries and identities because they are very porous even though they are artificially retained. In cultural terms, the research results show that it is not possible to say where the Greek end and where the Italian begin, because it does not make sense to speak of a unitary Greek or Italian community as a whole.

Another purpose of this paper has been to explore how participants in this study manage their Greekness and their hyphenated identity boundaries. The principal research questions concerned identity formation relating to othering and processes of individual and collective identifications. A key argument emerged from this field study is the importance of specific contexts, positions and conditions in which hybridity operates. The discontinuous line of double identities shows that Greek second generation members can act as either "Greek" or "Italian" depending on the circumstance and their self-interest, and can develop new hybrid forms. As a result, it is more accurate to speak of plural identities that are not only constantly negotiated but are also positional and situational. This means that Greekness is articulated within a range of different contexts and situations, where the Greek second generation often uses strategies through which identity is constructed contextually in relation to others. As Anthias argues (2001, 2013), recognizing the importance of the situational context and social relations of othering for self-attributions and hetero-attributions allows to overcome the notion of cultural fixity and elements of essentialism. Identities and their boundaries are considered to be mobile and constantly changing while hybridity stresses the dynamic and positional nature of identity.

Globalisation has resulted in the reinforcement of both supranational and sub-national regionalism, while leading often to a universalisation of particularism, that is, the global reach of particular identities. A case in point is represented by the effects caused by the European Union, where sovereignty is renewing its meaning by involving regionalism and subregionalism. The Greek debt crisis has highlighted the possible dangers for the European integration and the collective European identity, by uncovering not only the weaknesses and vulnerabilities of the economic governance of the euro area, but also the fragility of the idea of a collective European identity. If we want to fully understand the issues and dynamics of diasporas in an increasingly globalized and interconnected world, we cannot ignore the analysis of their dynamic, fluid and syncretic nature. Similarly, we cannot help associating diaspora and transnational movements of people and unlimited mobility of capital, goods, cultural iconography, positions, diasporic practices or idioms. This is even more important in reference to the historical period we are living today, in which the danger of cultural essentialism is resurfacing once again in Italy, in Greece and elsewhere in the European Union. In fact, over recent years we have been witnessing the growth and strengthening of extreme right-wing parties in Greece and Italy, as well as in other EU countries, concerned about the recent circumstances dealing with the "otherness" (massive flows of migrants, refugees and asylum seekers, threat of Islamic terrorism and so on). In their racialized 
discourse, the fixities of identity and culture represent a tool for reinforcing cultural hierarchies and hegemonic practices. For these political parties, boundary fetishism still exists through ethnicity, and hybridity is still seen as a threat for social order, a problem or an anomaly despite the fact that is everywhere. Adopting a hybridity perspective for diaspora studies means a challenge to all local claims of separate identities and fanaticism of cultural boundaries, by affirming an idea of intercultural society characterized by processes of continuity and discontinuity as well as deconstructing the notion of imagined community. In fact hybridity theory, in clarifying the shifting and indefinite nature of culture, could be a useful tool that undermine fixed and essential meaning, and complicate the nationalist exclusionary practice of determining who does and does not have claim to a nation. In an increasingly globalized world, hybridity could be considered as a lubricant in the clashes of culture and a good solution for a future free of xenophobia because it allows individuals to "negotiate across barriers language, cultural, spiritual, ritual and physical" (Iyall Smith 2008: 4). If we want to look ahead, it would be desirable to follow the approach of "globalisation-as-hybridisation" that considers the globalisation as a cultural form of diversification rather than homogenisation, and leads to hybrid identification and interculturalism, as opposed to the more static version of multiculturalism. European politics and projects should move in this direction and should feature prominently in critical discussions of hybridity overcoming traditional approaches to ethnicity and migration. If we want to understand cultural globalisation today we must bring hybridism to the fore because, using Ang's words, hybridity is a conceptual "point of departure from which to break from fundamentalist tendencies" (2003: 147).

\section{Acknowledgments}

I would like to thank the Greek Embassy and the Federation of Greek Communities and Brotherhoods of Italy for their moral support to my research.

\section{References}

Abatzopoulou F (1997) The image of the Jew in the literature of Salonica. In Ourselves and Others: the Development of Greek Macedonian Cultural Identity since 1912, P Mackridge, E Yannakakis (eds), 217-224. Oxford and New York: Berg.

Afentoulis M, Cleland A (2015) Diaspora at the crossroads: the future of Greek communities in Australia - a case study of two regional migrant communities. In Discovering Diaspora - A Multidisciplinary Approach, N Miletic, T Vekemans (eds), 37-48. Freeland: Inter-Disciplinary Press.

Al-Azmeh A (1993) Islams and modernities. London: Verso. 
Amselle JL (1999) Logiche meticce. Antropologia dell'Identità in Africa e Altrove [Mestizo Logics: Anthropology of identity in Africa and elsewhere]. Turin: Bollati Boringhieri.

Andall J (2002) Second-generation attitude? African-Italians in Milan. Journal of Ethnic and Migration Studies 28(3): 389-407.

Ang I (2001) On Not Speaking Chinese: Living between Asia and the West. London and New York: Routledge.

Ang I (2003) Together-in-difference: beyond diaspora, into hybridity. Asian Studies Review 27(2): 41-154.

Angouri J (2012) "I'm a Greek Kiwi": constructing Greekness in discourse. Journal of Language, Identity \& Education 11(2): 96-108.

Appadurai A (1996) Modernity at Large: Cultural Dimension of Globalization. Minneapolis: University of Minnesota Press.

Anthias F (2001) New hybridities, old concepts: the limits of "culture". Ethnic and Racial Studies 24(4): 619-641.

Anthias F (2002) Where do I belong? Narrating collective identity and translocational positionality. Ethnicities 2(4): 491-514.

Anthias F (2013) Intersectional what? Social divisions, intersectionality and levels of analysis. Ethnicities 13(1): 3-19.

Asher N (2008) Listening to hyphenated Americans: Hybrid identities of youth from immigrant families. Theory into Practice 47(1): 12-19.

Barth F (1969) Introduction. In Ethnic Groups and Boundaries: the Social Organization of Culture Difference, F Barth (Ed). Oslo: Norwegian University Press, 9-38.

Basch L, Glick Schiller N, Szanton Blanc C (1994) Nations Unbound: Transnational. Projects and the Deterritorialized Nation-state. London: Gordon and Breach.

Bhabha HK (1994) The location of culture. London and New York: Routledge.

Brettell CB, Nibbs F (2009) Lived hybridity: second-generation identity construction through college festival. Identities: Global Studies in Culture and Power 16: 678-699.

Burke P (2009) Cultural hybridity. Cambridge: Polity Press.

Butcher M (2004) Universal processes of cultural change: reflections on the identity strategies of Indian and Australian youth. Journal of Intercultural Studies 25(3): 215-231.

Callinicos C (1990) American Aphrodite: Becoming Female in Greek America. New York: Pella Press.

Chambers I (1996) Signs of silence, lines of listening. In The Post-colonial Question, I Chambers and L Curtis (eds), 47-62. London: Routledge.

Chasiotis IK, Katsiardi-Hering O, Ambatzi E (eds) (2006) Oi Ellines sti Diaspora 15os - 21os Aionas [Greeks in Diaspora $15^{\text {th }}-21^{\text {st }}$ Century]. Athens: Bouli ton Ellinon.

Christou A (2001) The struggle, success and national consciousness of the Greek diaspora in America. In American Studies at the Millennium: Ethnicity, Culture and Literature, L Koski, K Pajala (eds), 125-135. Turku: University of Turku Press.

Christou A (2006a) American dreams and European nightmares: experiences and polemics of second-generation Greek American returning migrants. Journal of Ethnic and Migration Studies 32(5): 831-845.

Christou A (2006b) Narratives of place, culture and identity: Second-generation Greek-Americans Return "Home". Amsterdam: Amsterdam University Press. 
Chryssanthopoulou V (2009) Gender and ethno-regional identity among Greek Australians: intersections. In Women, Gender and Diasporic Lives: Labor, Community and Identity in Greek Migrations, E Tastsoglou (ed), 197-227. Lanham: Lexington Books.

Conor BE (1991) Japan's new colony - America. Greenwich: Perkins Press.

Constantinou ST (1999) Dominant themes and intergenerational differences in ethnicity: The Greek Americans. Sociological Focus 22(2): 99-118.

Constantinou ST, Harvey ME (1985) Basic dimensional structure and intergenerational differences in Greek American ethnicity. Sociology and Social Research 69(2): 241-246.

Costantakos CM (1980) The American-Greek Subculture: Processes of Continuity. New York: Arno Press.

Dhingra P (2007) Managing multicultural lives: Asian American professionals and the challenge of multiple identities. Stanford, CA: Stanford University Press.

During S (2005) Cultural studies: A critical introduction. London: Routledge.

Dwyer C (2000) Negotiating diasporic identities: Young British South Asian Muslim women. Women's Studies Forum 23(4): 475-486.

Fabietti U (2003) L'identità etnica. Storia e critica di un concetto equivoco [Ethnic Identity. History and Criticism of a Misunderstanding concept]. Rome: Carocci.

Feinberg W (1993) Japan and the pursuit of a new American identity: Work and education in a multicultural age. New York: Routledge.

Frangoudaki A, Dragonas T (eds) (1997) Ti Einai i patrida mas; ethnokentrismos stin ekpaideusi [What our country is? Ethnocentrism in education]. Athens: Alexandria.

Georgakas D (1987) The Greeks in America. Journal of the Hellenic Diaspora 14(1-2): 5-53.

Gilroy P (1994) Black cultural politics: an interview with Paul Gilroy by Timmy Lott. Found Object, 4: 46-81.

Hall S (1996) Introduction: who needs identity?. In Questions of Cultural Identity, S Hall, P duGay (eds), 1-17. London: Sage.

Hannerz U (1992) Cultural complexity. Studies in the social organization of meaning. New York: Columbia University Press.

Hannerz U (1996) Transnational connections: Culture, people, places. London and New York: Routledge.

Hionidou V (2012) "Abroad I was Greek and in Greece I am a foreigner": Pontic Greeks from former Soviet Union in Greece. Journal of Modern Greek Studies 30(1): 103-127.

Hyun P (1995) In the new world: The making of a Korean American. Honolulu: University of Hawaii Press.

Hutnyk J (2005) Hybridity. Ethnic and Racial Studies 28(1): 79-102.

Iyall Smith KE (2008) Hybrid identities: theoretical examinations. In Hybrid Identities: Theoretical and Empirical Examinations, KE Iyall Smith and $\mathrm{P}$ Leavy (eds), 3-11. Leiden: Brill.

Kapardis A, Tamis A (eds) (1988) Afstraliotes Hellenes: Greeks in Australia. North Melbourne, VIC: Seine River Press.

Kibria N (2003) Becoming Asian American: Second-generation Chinese and Korean American. Maryland: Johns Hopkins University.

King R (2010) Geography and diasporas. In Dove Fnisce il Mare [Where the Sea Ends], M Iorio and G Sistu (eds), 195-212. Cagliari: Sandhi. 
King R, Christou A (2009) Cultural geographies of counter-diasporic migration: perspectives from the study of second-generation "returnees" to Greece. Population, Space and Place 16: 103-119.

King R, Christou A (2010) Diaspora, migration and transnationalism: insights from the study of second-generation "returnees". In Diaspora and Transnationalism. Concepts, Theories and Methods, R Baubök and T Faist (eds), 167-183. Amsterdam: Amsterdam University Press.

King R, Christou A, Ahrens J (2011) "Diverse mobilities": second-generation Greek-Germans engage with the homeland as children and as adults. Mobilities 6(4): 483-501.

Komondouros M, McEntee-Atalianis L (2007) Language attitudes, shift and the ethnolinguistic vitality of the Greek Orthodox community in Istanbul. Journal of Multilingual and Multicultural Development 28(5): 365-384.

Kontos M (2009) Greek migrant women in Germany: strategies of autonomy in diaspora. In Women, Gender, and Diasporic Lives: Labor, Community, and Identity in Greek Migrations, E Tastsoglou (Ed), 31-48. Lanham: Lexington Books.

Korinthios J (2012) I Greci di Napoli e del Meridione d'Italia dal XV al XX secolo [The Greeks of Naples and Southern Italy from XV to XX Century]. Cagliari: AM\&D.

Kornetis K (2007) Una diaspora adriatica: la migrazione degli studenti universitari greci in Italia [An Adriatic diaspora: the migration of Greek university students to Italy]. In Immaginare l'Adriatico. Contributi alla Riscoperta Sociale di uno Spazio di Frontiera, E Cocco and G Minardi (eds), 151-168. Milano: Franco Angeli.

Kosuka M (1989) Japans choice: New globalism and cultural orientation in an industrial State. London: Pinter.

Koukoutsaki-Monnier A (2012) Deterritorialising the nation? Internet and the politics of the Greek-American diaspora. Nations and Nationalism 18(4): 663683.

Kouvertaris G (1997) Studies on Greek Americans. New York: Columbia University Press.

Kraidy MM (2005) Hybridity: or the Cultural Logic of Globalization. Philadelphia: Temple.

Leavy P (2008) An introduction to the empirical examinations of hybridity. In Hybrid Identities: Theoretical and Empirical Examinations, KE Iyall Smith, P Leavy (eds), 167-178. Leiden: Brill.

Liu H (1998) Old linkages, new networks: the globalization of overseas Chinese voluntary associations and its implications. The China Quarterly 155: 588609.

Lo MCM (2002) Doctors Within Borders: Profession, Ethnicity, and Modernity in Colonial Taiwan. Berkeley: University of California Press.

Louie A (2004) Chineseness across borders: Renegotiating Chinese identities in China and the United States. Durham and London: Duke University Press.

Lowe L (1991) Heterogeneity, hybridity, multiplicity: marking Asian American differences. Diaspora: A Journal of Transnational Studies 1(1): 24-44.

Manousakas M (1991) Oi megales ellinikes paroikies tis Italias apo tin Alosi tis Konstantinoupolis (1453) os simera [The great Greek colonies of Italy from the Fall of Constantinople (1453) to Today]. In Proceedings of the First International Congress on the Hellenic Diaspora from Antiquity to Modern Times, JM Fossey (Ed). Amsterdam: J.C. Gieben, 1-12. 
Matsuda T (Ed) (2001) The age of creolization in the Pacific: In Search of emerging cultures and shared values in the Japan-America Borderlands. Hiroshima: Keisuisha.

McDuling A, Barnes L (2012) What is the future of Greek in South Africa? Language shift and maintenance in the Greek community of Johannesburg. Language Matters: Studies in the Language of Africa 43(2): 166-183.

Mitchell K (1997) Different diasporas and the hype of hybridity. Society and Space 15(5): 533-553.

Moran L (2016) Constructions of race: symbolic ethnic capital and the performance of youth identity in multicultural Australia. Ethnic and Racial Studies 39(4): 708-726.

Moskos CC (1999) Greek Americans: Struggle and success. New York: Transaction Publishers.

Nayak A (2003) Race, Place and Globalization: Youth Cultures in a Changing World. New York: Berg.

Nederveen Pieterse J (2005) Mélange globale. Ibridazioni e diversità culturali [Global mélange. Hybridizations and cultural diversity]. Rome: Carocci.

Neuliep JW (2009) Intercultural communication: A contextual approach. London: Sage.

Ngan LLS, Chan K-B (2012) The Chinese face in Australia. Multi-generational Ethnicity among Australian-born Chinese. London: Sprinter.

Nikas K (1991) Oi Ellines sti Neapoli apo ton 160 aiona mexri simera [The Greeks in Naples from the 16th century until today]. In Proceedings of the First International Congress on the Hellenic Diaspora from Antiquity to Modern Times, JM Fossey (Ed). Amsterdam: J.C. Gieben, 13-28.

Nilan P, Feixa C (2006) Introduction: youth hybridity and plural worlds. In Global Youth? Hybrid Identities, Plural Worlds, P Nilan, C Feixa (eds), 1-13. London: Routledge.

O'Connor P (2010) Everyday hybridity and Hong Kong's Muslim youth. Visual Anthropology 24(1-2): 203-225.

Panagakos A (2004) Recycled odyssey: creating transnational families in the Greek diaspora. Global Networks 43(3): 299-311.

Paulston CB (1992) Biculturalism: some reflections and speculations. In Sociolinguistic Perspectives on Bilingual Education, CB Paulston (ed), 116130. Philadelphia: Clevedon,

Petronoti M (2009) Black Greeks or white Africans? Landscapes of divergence and poetics of belonging. In Women, Gender, and Diasporic Lives: Labor, Community, and Identity in Greek Migrations, E Tastsoglou (Ed), 229-243. Lanham: Lexington Books.

Pelliccia A (2012) Ulysses Undecided. Greek Student Mobility in Italy. Rome: Aracne editrice.

Pelliccia A (2014) Modern Greek student mobility in Italy: between inaccessibility and social reproduction. Southeast European and Black Sea Studies 14(4): 530-547.

Phinney JS, Ong AD (2007) Conceptualization and measurement of ethnic identity: current status and future directions. Journal of Counseling Psychology 54(3): 271-281.

Pilkington H, Johnson R (2003) Peripheral youth: relations of identity and power in global/local context. European Journal of Cultural Studies 6(3): 259-283.

Plaza D (2006) The construction of a segmented hybrid identity among one-and-ahalf generation and second-generation Indo-Caribbean and African Caribbean 
Canadians. Identity: An International Journal of Theory and Research 6(3): 207-229.

Popov A (2010) Making sense of home and homeland: Former Greeks' motivations and strategies for a transnational migrant circuit. Journal of Ethnic and Migration Studies 36(1): 67-85.

Psomiades H (1987) Greece and Greek America: The future of the Greek American community. In Education and Greek Americans: Process and Prospects, S Orfanos, H Psomiades, J Spiridakis (eds), 91-102. New York: Pella.

Saloutos T (1964) The Greeks in the United States. Cambridge MA: Harvard University Press.

Scourby A (1980) Three generations of Greek Americans. A study in ethnicity. International Migration Review 14(1): 43-52.

Solaro A (2006) Italia. In Oi Ellines sti Diaspora 15os - 21os, IK Chasiotis, O Katsiardi-Hering and E Ambatzi (Eds). Athens: Bouli ton Ellinon, 158-163.

Stephenson M (2002) Travelling to the ancestral homelands: the aspirations and experiences of a UK Caribbean Community. Current Issues in Tourism 5(5): 378-425.

Taguieff PA (1987) La force du préjugé. Essai sur le racisme et ses doubles [The Force of Prejudice. On Racism and Its Doubles]. Paris: La Découverte.

Tamayo Lott J (1997) Asian Americans: From racial category to multiple identities. London: Sage and Altamira Press.

Tsolidis G (2009) Living diaspora "Back Home" - Daughters of Greek emigrants in Greece. In Women, Gender, and Diasporic Lives: Labor, Community, and Identity in Greek Migrations, E Tastsoglou (Ed), 181-196. Lanham, MD: Lexington Books.

Unger K (1986) Return migration and regional characteristics: the case of Greece. In Return Migration and Regional Economic Problems, R King (ed), 152-170. London: Croom Helm.

Vertovec S, Cohen R (eds) (1999) Migration, diasporas and transnationalism. Cheltenham: Edward Elgar Publishing.

Wang B, Collins FL (2016) Becoming cosmopolitan? Hybridity and intercultural encounters amongst 1.5 generation Chinese migrants in New Zealand. Ethnic And Racial Studies 39(15): 2777-2795.

Waters MC (1990) Ethnic options: Choosing identities in America. Berkley: University of California Press.

Werbner P (2001) The limits of cultural hybridity: on ritual monsters, poetic licence and contested postcolonial purifications. The Journal of the Royal Anthropological Institute 7(1): 133-152.

Whatmore S (2002) Hybrid geographies: Managements, cultures, spaces. London: Routledge.

Yang J, Gan D, Hong T (1997) Eastern standard time: A guide to Asian influence on American culture from Astro Boy to Zen Buddhism. Boston MA: Houghton Mifflin.

Yow C (2010) A question of priorities: Unmapping through a diasporic femininity. Vancouver: University of British Columbia. 